УДК 32.019.51

\title{
ВЛИЯНИЕ КУЛЬТУРНЫХ ФАКТОРОВ НА ПОЛИТИКУ ДЕКОММУНИЗАЦИИ В СОВРЕМЕННОЙ ПОЛЫШЕ
}

\author{
Нагорных Олег Владимирович \\ аспирант \\ Научный руководитель: Керимов Александр Алиевич \\ Д.П.Н. \\ Уральский федеральный университет \\ имени первого Президента России Б.Н. Ельцина
}

\begin{abstract}
Аннотация: Процесс декоммунизация можно рассматривать с разных точек зрения. Наиболее широко используются точки зрения, созданные политологами и экспертами, указывающие на структурные, системные и экономические изменения. Такого рода анализы пытаются объяснить падение коммунистического режима, ссылаясь, например, на внутренние и международные события, партийные союзы и даже личные связи основных действующих лиц на политической сцене. Большинство таких исследований страдают от незнания более глубоких исторических и социологических корней событий, разворачивающихся в данной области. В данной статье автор на примере Польши доказывает важность культурных факторов, влияющих на политику декоммунизации.
\end{abstract}

Ключевые слова: декоммунизация, национализм, каталицизм, политическое сознание, культура, мессианство.

\section{THE INFLUENCE OF CULTURAL FACTORS ON THE POLICY OF DECOMMUNIZATION IN MODERN POLAND}

\section{Nagornykh Oleg Vladimirovich Scientific adviser: Alexander Aliyevich Kerimov}

\begin{abstract}
The process of decommunization can be viewed from different perspectives. The most widely used viewpoints are those created by political scientists and experts that point to structural, systemic, and economic changes. Such analyses attempt to explain the fall of the communist regime by referring, for
\end{abstract}




\section{НАУКА, ОБЩЕСТВО, КУЛЬТУРА: ПРОБЛЕМЫ И ПЕРСПЕКТИВЫ ВЗАИМОДЕЙСТВИЯ В СОВРЕМЕННОМ МИРЕ}

example, to domestic and international events, party alliances, and even the personal connections of the main actors on the political scene. Most of these studies suffer from ignorance of the deeper historical and sociological roots of events unfolding in this field. In this article, the author uses the example of Poland to prove the importance of cultural factors that influence the policy of decommunization.

Key words: decommunization, nationalism, catholicism, political consciousness, culture, messianism.

Термин декоммунизация в польской общественной жизни встречается в двух значениях. В более широком смысле это означает системное изменение, состоящее в разрушении коммунистической системы, то есть переходе от коммунизма, а также всех действиях, служащих этим изменениям. В свою очередь, декоммунизация в более узком смысле может означать чистку или проверку (люстрацию), проводимую в реалиях падения коммунизма.

В отчете для Парламентской ассамблеи Совета Европы Адриан Северин (Adrian Severin) определяет декоммунизацию как «процесс преодоления наследия тоталитарных коммунистических систем», состоящий в «ликвидации тоталитарного законодательства, институтов, методов и стратегий управления, прежнего менталитета и личных структур (номенклатуры)» [1]. Адам Чарнота (Adam Czarnota) выделяет более широкое и узкое значение термина. В широком значении декоммунизация означает «все политические и правовые стратегии, направленные на искоренение наследия коммунизма из политической и социальной системы» [2]. В этом смысле декоммунизация будет означать как процесс перехода от коммунизма, так и действия, обслуживающие этот процесс. В более узком смысле, как «Процедура, позволяющая исключить из общественной жизни группу людей, которые в прошлом занимали определенные должности в государстве и / или коммунистической партии» [3].

Войцех Садурский (Wojciech Sadurski) указывает, что декоммунизация обычно означает «удаление бывших членов коммунистической партии (выше определенного уровня) с видных позиций в новой демократической системе», таким образом, это является выражением коллективного удаления определенных категорий людей из государственных учреждений [4].

Бронислав Геремек (Bronisław Geremek) и Александр Квасьневский упоминаются среди сторонников понимания декоммунизации как перехода от коммунизма к демократии. Ярослав Качиньский [5] был сторонником понимания его как средства демократии, необходимого для возникновения демократии. 


\section{НАУКА, ОБЩЕСТВО, КУЛЬТУРА: ПРОБЛЕМЫ И ПЕРСПЕКТИВЫ ВЗАИМОДЕЙСТВИЯ В СОВРЕМЕННОМ МИРЕ}

В результате этих определений декоммунизации, мы не находим оснований формирования данного процесса. В данной статье мы попробуем выявить сущностные характеристики данного процесса в Польше.

Польша была самым упорным и мятежным членом советского блока, и со временем поляки приобрели степень свободы, недоступную в других странах. Достаточно упомянуть частное сельское хозяйство, свободу вероисповедания и сильную позицию католической церкви, а также терпимость к диссидентским группам, которая вылилась в Солидарность, массовое движение с почти десятью миллионами членов, совершенно независимое от государства. К этому списку следует также добавить такие элементы, как относительная, но растущая свобода передвижения, свобода культурного самовыражения и свобода исследований в области социальных и гуманитарных наук. Ученым не приходилось заявлять о своей идеологической приверженности марксизму, и они часто критиковали его, заявляя о своей приверженности другим теоретическим направлениям.

Несомненно, экономический кризис стимулировал неповиновение авторитарному государству, но не может объяснить феномен. Условия жизни были сравнительно суровыми в ряде других коммунистических стран, например, в Албании, Румынии, советских республиках и Болгарии, но нигде инакомыслие не процветало в таких масштабах, и освобождение граждан от государственного контроля не стало настолько реальным и очевидным, как в Польше. Вот почему следует искать формы и методы проведения декоммунизации в культурной сфере.

В истории польской культуры можно выделить влияние различных традиций. Мы выделяем 3 наследия, которые сыграли роль в формировании политического сознания Польши: патриотизм/национализм, католицизм и мессианство.

Интернационализм был одним из самых ярких лозунгов коммунизма, и товарищеские отношения последовательно пропагандировали эту идею. Однако в Польше это противоречило традиции национальной независимости, за которую нация боролась, обычно против русских, в течение ста пятидесяти лет. В сталинский период традиционное польское наследие подавлялось, но, власти вскоре узнали, что вместо того, чтобы искоренить его, они должны его использовать. Национализм ускорил Октябрьскую оттепель 1956 года, и к власти пришел Владислав Гомулка. Позже, в 1968 году, он попытался извлечь выгоду из националистической ксенофобии в антисемитской кампании. 


\section{НАУКА, ОБЩЕСТВО, КУЛЬТУРА: ПРОБЛЕМЫ И ПЕРСПЕКТИВЫ ВЗАИМОДЕЙСТВИЯ В СОВРЕМЕННОМ МИРЕ}

Националистические настроения были вызваны также Эдвардом Гереком в 1970-х годах, что выразилось в популярном лозунге того времени: "пусть Польша растет в силе, а ее народ живет в процветании". Войцех Ярузельский прилагал все усилия, чтобы убедить людей в своем патриотизме, и его политика требовала частых намеков на патриотическое и военное наследие. Польские коммунисты, в отличие от правителей других советских сателлитов в Центральной Европе, сохранили атрибуты национальной идентичности почти неизменными: флаг, гимн и печать белого орла, хотя и некоронованного. СССР не высказывала свое недовольство на использование таких национальных символов, и политическая борьба 1980-х годов может быть понята также как борьба за контроль над этими символами, национальными ритуалами, героями и т. д. [7].

Роль каталицизма в формировании политического сознания граждан Польши трудно недооценить. Нация, лишенная подлинной политической автономии, нашла частичное воплощение в религии. Поскольку такие области общественной культурной жизни, как официальное школьное образование и средства массовой информации, находились под контролем государства, националистические чувства все чаще направлялись в религиозную жизнь область все чаще, хотя и только после длительной борьбы, оставалась вне сферы партийного контроля. Религиозные ритуалы регулярно превращались в демонстрацию несогласия людей с навязанной им системой. Католическая церковь в то же время взяла на себя роль хранителя национальной культуры: церковные здания служили убежищами для культурной и политической деятельности, а священники взяли на себя роль хранителей нравов нации. Таким образом, религиозное и национальное наследие усилили друг друга и слились.

Философия польского романтического мессианизма сыграла так же одну из важных ролей в польском менталитете. Мессианизм утверждал, что польская история повторит историю спасения. Польша, подобно Христу, будет страдать, чтобы дать свободу человечеству. Такой взгляд на историю придавал смысл страданиям и любой борьбе за свободу, даже той борьбе, которая с самого начала была обречена на неудачу [8, с. 5]. Выдающийся польский ученый Мария Янион в конце 2000-х годов отмечала: "мессианские идеи чаще всего компенсируют чувство незаслуженной социальной несправедливости, вызванной трансформацией свободного рынка" [9, с. 308]. Политические элиты, особенно правые националисты, широко использовали рассказы о 


\section{НАУКА, ОБЩЕСТВО, КУЛЬТУРА: ПРОБЛЕМЫ И ПЕРСПЕКТИВЫ ВЗАИМОДЕЙСТВИЯ В СОВРЕМЕННОМ МИРЕ}

коллективной борьбе и страданиях, чтобы завоевать электорат, который чувствовал себя дезориентированным и исключенным из мира быстрых культурных и социальных перемен. Знакомые мифы давали утешение и давали простые объяснения сложным глобальным процессам, но обвинение могущественных "других" (коварных соседей, внутренних предателей или лживого Запада) во всех негативных или болезненных последствиях посткоммунистического перехода только углубляло поляризацию польского общества. Мессианизм, как утопия, был кодифицирован в произведениях наиболее выдающихся романтических поэтов: Мицкевича, Словацкого и Красинского.

Таким образом, рассмотренные нами ментальные установки сыграли центральную роль в создании польского политического сознания. Некоторые модели мышления и поведения унаследованы от прошлого, даже если они, очевидно, постоянно меняются в настоящем. Процесс декоммунизации, представляет собой сложную структуру, опирающуюся на культурные и исторически сложившиеся установки. Данный факт широко используется политическими силами в борьбе за политическую власть.

\section{Список литературы}

1. Adrian Severin. Меры по демонтажу наследия бывших коммунистических тоталитарных систем (документ 7568). Доклад Адриана Северина для Комитета Парламентской Ассамблеи Совета Европы по правовым вопросам и правам человека, 03.06.1996. [online] Доступ: 27.05.2020. параграф 5 http://assembly.coe.int/nw/xml/XRef/X2H-Xref-

ViewHTML.asp?FileID=7506\&lang=EN\#_ftn1

2. Adam Czarnota. Lustration, Decommunisation and the Rule of Law, s. 310.

3. Adam Czarnota, Lustration, Decommunisation and the Rule of Law, s. 311.

4. Wojciech Sadurski. "Decommunisation", "Lustration" and Constitutunal Continuity: Dilemmas of Transitional Justice in Central Europe. European University Institute, 2003. [online] Dostęp: 26.12.2009. Dostępny w internecie: http://cadmus.eui.eu/dspace/bitstream/1814/1869/2/law03-15.pdf, s. 4

5. Jerzy Machejek, Jan Olczyk, Andrzej Machejek, Kwaśniewski. „Nie lubię tracić czasu!’. Wywiad-rzeka z liderem SLD, Łodź, 1995, s. 88-89

6. Ракитянский H.M. Сарматизм-ментальная основа шляхетской республики речи посполитой. Информационные войны. 2010. № 3 (15). С. 8087. 
7. Mach, Z. 1989. Symbols, conflicts and identity. Krakow: Uniwersytet Jagiellonski.

8. Ash T.G. The Polish Revolution: Solidarity, London: Penguin Books, 1999, p. 5 .

9. Janion M. Niesamowita Słowiańszczyzna, Kraków: Wydawnictwo Literackie, 2007, p. 308. 